\title{
Changes in the Music Scene in Slovenia after 1918
}

\author{
Jernej Weiss / jernej.weiss@ag.uni-lj.si
}

Academy of Music, University of Ljubljana, Lubljana, SI

\begin{abstract}
Following the First World War, radical cultural changes took place in central and eastern Europe. After more than 600 years, the Slovenes bid farewell to the Habsburg monarchy, and, together with the Croats and Serbs formed the new State of Slovenes, Croats and Serbs on 29 October 1918. The end of ties with the Habsburg Monarchy and the new geographical, political, economic, cultural and linguistic environment also had a significant effect on the organisation and operation of Slovene cultural and academic institutions. Two important processes took place in the musical sphere: the nationalisation of key Slovene musical institutions (in the sense of a transformation from provincial institutions to national ones) and the Slovenisation of formerly German cultural institutions. In the years immediately after the Great War, Ljubljana gained several long-awaited professional cultural and academic institutions of key national importance, including a university, a national theatre and a conservatory. Naturally, the importance of these institutions was not only in the cultural or academic aspects of their work. Equally important, or for some contemporaries, even more important, was the fact that the process of formation of these institutions represented a decisive step towards the national emancipation of Slovenes into the circle of culturally developed nations.
\end{abstract}

\section{Keywords}

World War I, Slovene, German, Glasbena Matica, Philharmonic Society, Conservatory

This article is a part of the research project nr. J6-8261, financed by the Slovenian Research Agency from the state budget. 


\section{Music institutions in Slovenia on the eve of the First World War}

At the turn of the century and up until the beginning of the First World War, the musical pulse of Ljubljana was beating stronger than ever. The unique rivalry between its two competing musical institutions resulted in new achievements, and the circumstances of that time allowed them both to shine in their own way: the Glasbena Matica music society excelled principally in the choral field, while the Philharmonische Gesellschaft (Philharmonic Society), established in 1794, led the way in the performance of chamber and symphonic music. ${ }^{1}$

However, it was the conflicts and the increasingly apparent divisions between the two key political perspectives in Slovenia, the liberals and the clericalists, that had already begun to interfere in the lives of these two cultural institutions a few years prior to the Great War, and brought about disastrous consequences in 1913.

It is alleged that the various scandals on the clericalist side, which the liberals made very good use of, led the conservatives to take their revenge on the "liberal institutions", which needed the support of the provincial government, where the conservatives had a majority. As a result, they withdrew their support from the Glasbena Matica, having already done the same to the Slovenian Philharmonic and the Slovene theatre company at the Provincial Theatre. Despite emphasising that the management of cultural institutions should be a cultural rather than political issue for all Slovenes, the Provincial Council maintained its views. ${ }^{2}$

The result was frightening: the Slovenian Philharmonic Orchestra (which under the leadership of Václav Talich notched up several enviable artistic achievements from 1908 to 1912) was no more, the Slovene theatre and opera companies based at the Provincial Theatre and ceased their activities, and the most important music magazine Novi akordi ["New Chords"], the final issues of which began dealing with certain critical concerns regarding Slovene music, ceased publication. Its Vienna editor Gojmir Krek stood out against the "rotten circumstances" ${ }^{3}$ in Slovene cultural policy.

The Glasbena Matica music society in Ljubljana managed to survive and strived to follow a non-party policy, but neither side was happy with this. ${ }^{4}$ The negative views held towards the Glasbena Matica are also evident from numerous newspaper reports of the time. Ivan Štefe, a journalist at Slovenec ["The Slovene"], the then leading newspaper of political Catholicism in Slovenia, wrote these harsh words: "Although we will not attack the Glasbena Matica outright, our ultimate aim is to destroy it."

1 KOTER, Darja. Slovenska glasba 1848-1918. Ljubljana: Študentska založba, 2012, p. 267.

2 KURET, Primož. Ljubljanska filharmonična družba 1794-1919: kronika ljubljanskega glasbenega življenja v stoletju meščanov in revolucij. Ljubljana: Nova revija, 2005, p. 406.

3 KREK, Gojmir. Dostavek uredništva. Novi akordi: glasbeno-književna priloga 13, 1914, no. 1, p. 23.

4 KRSTULOVIĆ, Nataša Cigoj. Zgodovina, spomin, dediščina: Ljubljanska Glasbena matica do konca druge svetovne vojne. Ljubljana: Založba ZRC, 2015, p. 85-92.

5 KURET, Primož. Ljubljanska filharmonična družba, op. cit., p. 406. 


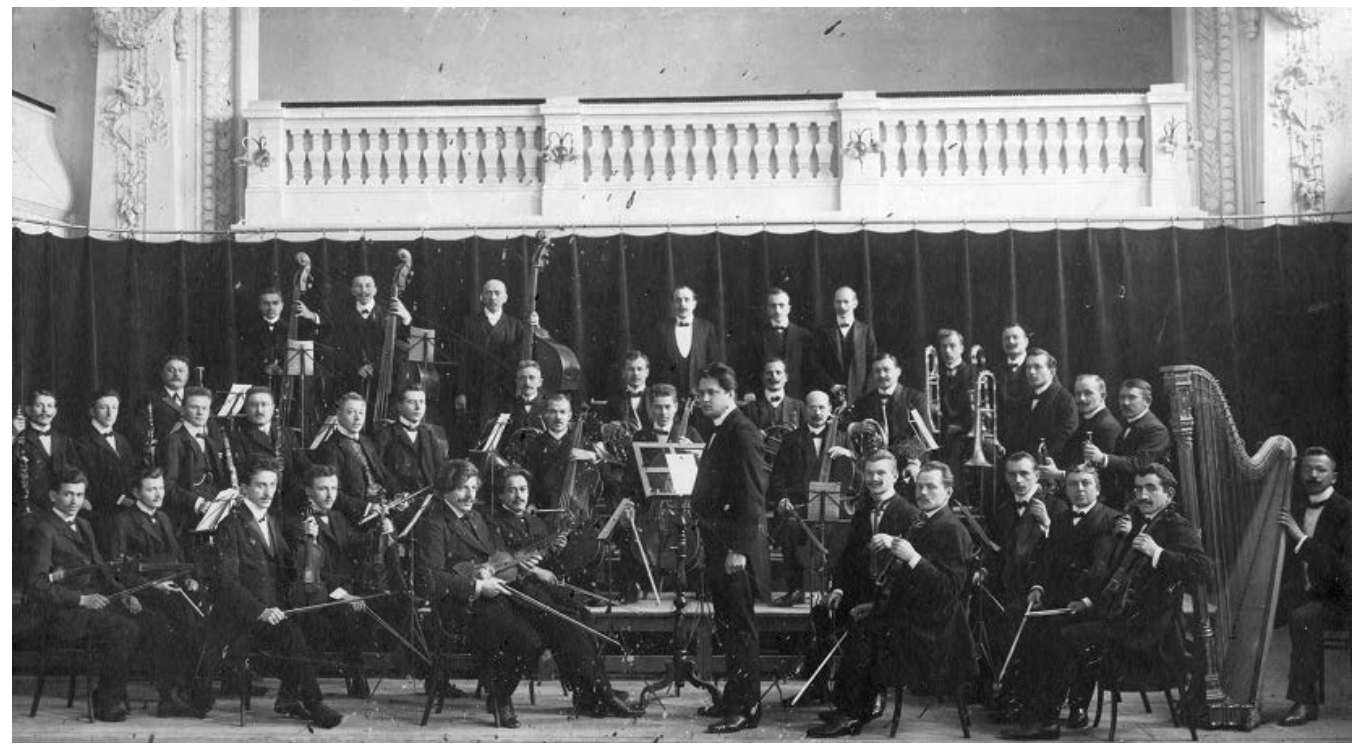

Fig. 1 The young maestro Talich, with the then 37-member orchestra of the Slovenian Philharmonic Orchestra which could be called also the second Czech Philharmonic, since more than half of its members were Czech musicians working in Slovenia.

Such a position against the main sponsor of the majority of Slovene music societies naturally could not have had a favourable impact on the growth and development of Slovene musical culture. It can therefore be said that in the area of pre-war musical culture, the Slovenes were their own worst enemy, since discord, factiousness and mutual opposition were what caused the most damage to musical development and the progress of Slovenia's burgeoning music culture.

The venerable "German" Philharmonic Society in Ljubljana faced no such problems, at least not to an extent that would seriously jeopardise its normal functioning. Despite the impending war, its membership continued to grow, ${ }^{6}$ and philharmonic concerts were conducted more or less undisturbed.

In this regard, the testimony of a German living in Celje, Fritz Zangger, is worthy of note; Zangger wrote that "the social and cultural life of Ljubljana before the First World War was at an enviable level". ${ }^{7}$ He even believed that no other similar-sized city in the Monarchy could compare with Ljubljana in this regard, which appears somewhat exaggerated given the varied cultural life of some of the other cities in the Austro-Hungarian Monarchy.

6 As an example, nearly the entire officers' choir of the 27th Infantry Regiment in Ljubljana joined the Ljubljana Philharmonic Society. KURET, Primož. Ljubljanska filharmonična družba, op. cit., p. 408.

7 ZANGGER, Fritz. Das ewige feuer im fernen Land: Ein deutsches Heimatbuch aus dem Südosten. Celje: Druckerei u. Verlags AG, 1937, p. 98. 


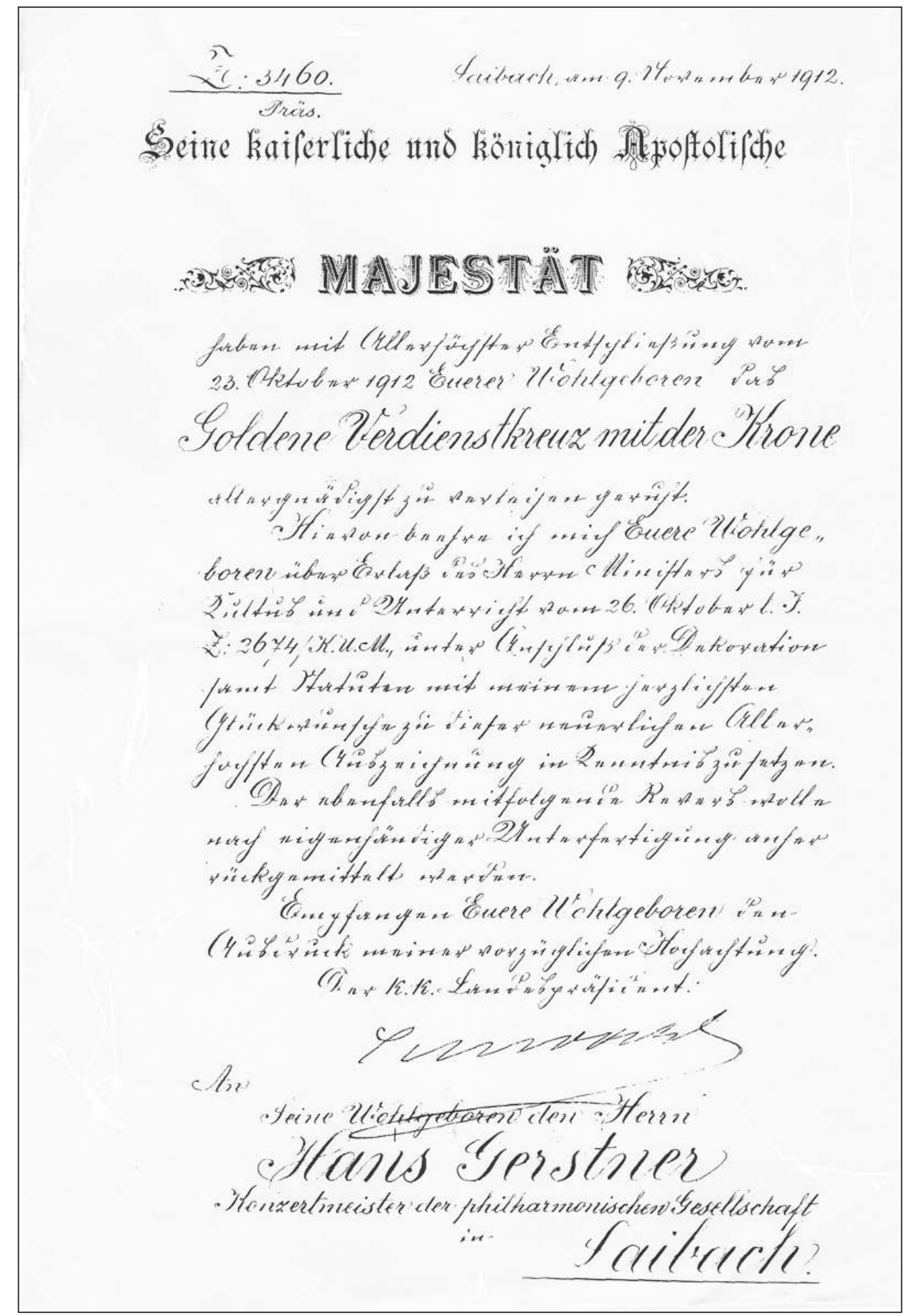

Fig. 2 On 9 November 1912, Emperor Franz Joseph awarded Hans Gerstner the Golden Cross of Merit with Crown, one of the highest state awards. 
The work of the Philharmonic Society, which alongside the German Provincial Theatre was then still the principal music institution in Slovenia, was influenced more heavily by certain management-related changes, as the conclusion of the 1911/12 season saw the long-time music director of the Philharmonic Society, Josef Zöhrer, announce his retirement. The leadership was assumed by the elderly concertmaster Hans Gerstner, ${ }^{8}$ who from the autumn of 1914 to late June 1919 was responsible for virtually everything connected with the work of the Philharmonic Society in Ljubljana, ${ }^{9}$ otherwise one of the oldest philharmonic societies in the Habsburg Monarchy. ${ }^{10}$

The situation at the German Provincial Theatre in Ljubljana was even more complex. With the opening of the new German theatre dedicated to the Emperor Franz Joseph in the autumn of 1911, the German Provincial Theatre realised its long-cherished ambition of wresting itself from the grip of Slovene theatre, which was increasingly limiting its activity and gradually driving it out of its original home. Previously, both companies were housed at this location, where they shared the so-called performance days. ${ }^{11}$ Thus, in the 1911/12 season both the Germans and the Slovenes achieved their long-held desire to have their own theatre, although this did not guarantee the survival of either company. While the predominantly liberally oriented Slovene management faced the aforementioned internal political pressures, the Germans found themselves losing out in an increasingly Slovene Ljubljana ${ }^{12}$ that was too small to sustain two theatrical institutions. In turn, these factors led to the closure of both theatres, which had shaped the musical and stage image of the capital for two decades prior to the First World War.

\section{Nationalisation of music institutions after the First World War}

After the First World War, radical changes were observed in the cultural image of central and eastern Europe. After more than 600 years, the Slovenes bid farewell to the Habsburg monarchy, and, together with the Croats and Serbs on 29 October 1918 (only one day after the independence was declared by the First Czechoslovak Republic) formed

8 In a typescript dated as early as 20 October 1910, the management asked Gerstner to take over responsibility for the philharmonic orchestras, a task that was said to be of great artistic and national importance. Die Philharmonische Gesellschaft in Laibach, 20 October 1910, Ljubljana, Gesellschaft der Musikfreunde in Wien, Archiv.

9 WEISS, Jernej. 'Even Amidst the Clash of Conflict, the Sweet Sounds of the Muses did not Fade Away Completely': The Concert Life of the Philharmonic Society in Ljubljana in the Period of its Last Music Director Hans Gerstner. Muzikološki zbornik 53, 2017, no. 2, p. 149-171.

10 KURET, Primož. Filharmonična družba - najstarejše glasbeno društvo v monarhiji. Slovenska kronika XIX. stoletja. Ljubljana: Nova revija, 2001, p. 48.

11 LAH, Špela. Slovensko-nemška dihotomija v Deželnem gledališču v Ljubljani med letoma 1892 in 1914. Muzikološki zbornik 46, 2010, no. 2, p. 97.

12 MATIĆ, Dragan. Nemci v Ljubljani: 1861-1918. Ljubljana: Oddelek za zgodovino Filozofske fakultete, 2002, p. 433. 
the State of Slovenes, Croats and Serbs. With the entry of the Slovenes into the new southern Slav state, Slovene cultural development gained new impetus. Similar to other cultural institutions, two processes were executed in the music field: the nationalisation and the Slovenisation of the former German cultural institutions.

\section{The National Theatre Opera in Ljubljana}

Before the war, as mentioned, two provincial theatre companies - one Slovene and one German - had operated in Ljubljana. The Slovenes were of the view that the German theatre was no longer needed, since a large portion of the German-speaking elite had moved north to the German-speaking lands. For their first production in the former German theatre they selected the play Tugomer by Slovene writer Josip Jurčič, a work which was banned from performance in Ljubljana during Austro-Hungarian times. The play, which earned an exceptional reception from the public, depicts the fate of the Polabian Slavs in the 10th century, when neighbouring Germanic peoples waged war against them. In contemporary circumstances the play supposedly portrayed how, a thousand years later, in the clash between the Slavs and Germans in the Slovene lands it was the Slovenes who were victorious.

At the same time, there was nothing coincidental also about the choice of the first post-war opera production, The Bartered Bride by Bedřich Smetana, which given the number of performances (up until the First World War, it had been performed more than 50 times at the Slovene Provincial Theatre) could even be regarded as a second Slovene "national" opera. ${ }^{13}$ Especially if we note that Smetana's Czech colleague working in Slovenia, Anton Foerster, in his opera Gorenjski slavček ["The Nightingale of Upper Carniola"] drew heavily on the aforementioned Czech opera; the rural essence of both operas was a perfect match for the contemporary Slovene national identity. ${ }^{14}$

The very next day after the first performance, on 3 December 1918, an anonymous critic wrote in the newspaper Slovenski narod ["The Slovene Nation"] that with the staging of The Bartered Bride the "new Slovene opera theatre had celebrated its resurrection"15. The critic continued that after the initial successes at the new Provincial Theatre, Slovene opera "had been in decline, until present circumstances reduced it to a point where it appeared dead." ${ }^{16}$ But this was now surely a thing of the past, for "yesterday we saw it again and it appeared virtually finer than in the finest period of its existence!" 17

13 MORAVEC, Dušan (ed.). Repertoar slovenskih gledalǐ̌č 1867-1967. Ljubljana: Slovenski gledališki muzej, 1967, p. 181-201.

14 WEISS, Jernej. Med provincialno opereto in nacionalno opero Foersterjev Gorenjski slavček. In Musica et artes. Koper: Založba Univerze na Primorskem; Ljubljana: Akademija za glasbo: Festival Ljubljana: Slovenska filharmonija, 2015, p. 59-75.

15 N. Narodno gledališče. Slovenski narod, no. 288, 4 December 1918, p. 3.

16 Ibid.

17 Ibid. 
It should be stressed that the reliance on Slavic, primarily the Czech models, is very characteristic for pre-war Slovene opera production and performance. Opera performances were mostly dominated by Czech musicians. For example, in 1896, the premiere of the already mentioned Gorenjski slavček - today considered the first Slovene opera - written by the Czech composer Anton Foerster was conducted by Czech conductor Hilarion Beníšek, while the reviewer was Czech critic Karel Hoffmeister, etc.

\section{The Conservatory of the Glasbena Matica in Ljubljana}

In general, the crisis of educated Slovene performers and composers was something that was gradually solved by the establishment of the Conservatory at the Glasbena Matica in Ljubljana, which started operating in September 1919. Its importance for Slovene musical culture is historic. The Music Conservatory was based on the example of the Prague Conservatory, and his management role also included the work of the Zagreb Conservatory, which had been established three years earlier.

Nonetheless, its establishment was the fruit of several years of efforts by Slovenes to raise the level of music education. The initiative for carrying out this plan was set in motion by certainly one of the most influential musicians of that time in Slovenia, Matej Hubad, principal of the Glasbena Matica music school and its musical director. ${ }^{18} \mathrm{He}$ wrote that "The Conservatory should be the cultural centre of musical, operatic and dramatic art" assessing this as a condition for establishing Yugoslav culture as an equal to others, so that "it would be able to compete with global cultural nations". ${ }^{19}$

The start of activities at the Conservatory, which was nationalised in 1926 and two decades later reorganised as the Music Academy, therefore has historic significance for Slovene musical culture. The founding was the fruit of lengthy efforts by Slovenes to raise the level of music education and to professionalise musical activity in the heart of the nation, Ljubljana.

The purpose of music education at the Ljubljana Conservatory was the same as elsewhere in Europe: to provide the necessary foundations for professional music-making. Its activities after the First World War accelerated the professionalisation and specialisation of musical life among the Slovenes. Importantly, its establishment brought higher music education into contact with contemporary pedagogical approaches from abroad. Although operating in modest conditions, the Conservatory achieved noteworthy and sometime enviable results. In fact, until the Second World War, it was the only arts education institution in Slovenia to award state-approved diplomas, since plans to establish similar schools for the theatre and fine arts were not realised until after the war.

18 KRSTULOVIĆ, Nataša Cigoj. Zgodovina, spomin, dediščina, op. cit., p. 164-67.

19 HUBAD, Matej. Jugoslovanski konservatorij Glasbene Matice v Ljubljani. Učiteljski tovariš, vol. 59, no. 35, 27 August 1919, p. 1. 
In order to accelerate the resolving of increasingly important cultural policy issues, a theatre commission was established on 7 November 1919, alongside the commission for teaching and religious observance, another state authority that had a significant influence on the musical image of cultural institutions. Its area of work was to assist in organising the entire cultural sphere, and not just its theatrical dimension. The aforementioned musical director of the Glasbena Matica, Matej Hubad, was appointed to the theatre commission, along with the composers Fran Kimovec, the previously mentioned Gojmir Krek and Anton Lajovic, who played an extremely important part in the Slovenisation of the "German" Philharmonic Society in Ljubljana. ${ }^{20}$

\section{Slovenisation of "German" cultural institutions in Ljubljana}

In the changed politico-cultural situation after the war, the Philharmonic Society found itself in completely new circumstances. The fact that the venerable Philharmonic Society was unable to comprehend the new era is evidenced by its appeal to the remaining members to stay loyal and for new members to join as it is a matter of "German honour to preserve the ancient society, which was bound only to the German part of the population since the establishment of the Glasbena Matica in 1872, in the spirit of the old tradition". ${ }^{21}$ Members were reminded of the past crises that the Academia Philharmonicorum had experienced since its establishment in 1701, the Franco-German War and other obstacles, which the Philharmonic Society had always been able to surmount. In a similar spirit, the Society would be able to overcome the latest crisis and begin organising concerts again.

The appeal, however, came too late. A representative of the state, and later member of the theatre commission, also one of the main composers of that period, Anton Lajovic, opposed all of the decisions and actions taken by the last general assembly of the Society held on 10 April 1919, and halted all its activities in June 1919, discharging the presidency and demanding that the entire property of the Philharmonic Society be handed over to him. ${ }^{22}$

I should point out that extensive diary of the final years of operation of the Philharmonic Society was preserved, written by the already mentioned last director, namely Sudeten German Hans Gerstner. ${ }^{23}$ This record reflects his disappointment regarding the actions of the new authorities, which had appropriated and passed on the entire property and all activities of the Society to the Glasbena Matica, which until recently had been a competitive institution; this featured numerous instruments along with other

20 Ustanovitev gledališke komisije. Uradni list deželne vlade za Slovenijo, I, no. 165, 26 November 1919 , p. 606.

21 KURET, Primož. Ljubljanska filharmonična družba, op. cit., p. 442.

22 Ibid.

23 GERSTNER, Hans. Ein Leben für die Musik. Hans Gerstner, 17.08.1851, Luditz - 09.01.1939, Laibach. Unpublished manuscript, Archive, Sudetendeutsches Musikinstitut, Regensburg. See also: WEISS, Jernej. Hans Gerstner (1851-1939): življenje za glasbo. Maribor: Litera, 2010. 
valuable objects kept by the Society, including Beethoven's letter ${ }^{24}$ to the Philharmonic Society and a pension fund worth as much as three million crowns. After the war, these efforts were also about showing power over all things German, which led Lajovic a few years later to utter his famous words about "the poison of Beethoven, Bach and Wagner works" for the musical culture in Slovenia. ${ }^{25}$

Gerstner addressed several appeals to the new capital, Belgrade, to prevent this "unjust robbery." ${ }^{26}$ After the merger into the Kingdom of Serbs, Croats and Slovenes on 1 December 1918, politico-cultural questions fell under the formal competence of the Ministry of Education in Belgrade. His efforts came to no avail; however, as Lajovic was a judge he was able to legally prevent any such requests from being granted every time.

Indeed, the period of new politico-cultural reality for those rare "German" musicians who remained in Slovenia after the First World War was a difficult time. After 48 years of service, therefore, Gerstner retired with a then extremely miserly pension of 333 crowns, which barely sufficed for his survival. So, the then elderly master of over 60 years had to get by providing private tuition and he was ultimately even forbidden from entering the philharmonic hall built in 1891, the Tonhalle, today the building of the Slovenian Philharmonic, where previously he had performed so many times as a soloist and concertmaster. ${ }^{27}$

The Philharmonic Society appealed, but to no avail. These events were also reported in the press. Expounding his views in Slovenski narod, Lajovic denounced the Society for its pro-German orientation - among other things, the fact that it failed to support the Slovenian Philharmonic Orchestra in 1908 - and justified the measures he had taken as the protection of national property against its German managers. In his view, the latter were aiming to "deceitfully misappropriate collective property from its essential purpose". ${ }^{28}$

The newly-elected President of the Society, the dentist Dr Schweiger, in turn accused Lajovic of illegal conduct and abuse of power. He rejected the allegation regarding the establishment of a joint orchestra, opposed Lajovic's views on the distribution of assets, and accused him of ignoring the rule according to which the property of the Society, in the case of its dissolution, was at the disposal of its last general assembly. He highlighted that for over two centuries the Society had been a cultural institution detached from politics, and that the fact that most of its members were German should not be used against it. ${ }^{29}$

24 Beethoven's letter of gratitude upon being made an honorary member of the Philharmonic Society, dated 4 May 1819. GERSTNER, Hans Jr. Die Philharmonische Gesellschaft in Laibach. In Südostdeutsche Vierteljahresblätter, Sonderdruck aus Heft Nr. 3, 1972, p. 168-169. After WWI, Beethoven's letter was sold to the Zürich collector H. C. Bodmer, and in 1956 to the Beethoven-Haus archives in Bonn where it is still kept today. DUFNER, Jens. Beethoven Werke, Symphonien III. München: Franz Steiner Verlag, 2013, p. 277.

25 LAJOVIC, Anton. O večnih krasotah in o strupu Beethovnovih, Bachovih in Wagnerjevih del. Slovenec, no. 80, 6 April 1924, p. 5.

26 GERSTNER, Hans. Ein Leben für die Musik. Hans Gerstner, op. cit., p. 96.

27 GERSTNER, Hans Jr. Die Philharmonische Gesellschaft in Laibach, op. cit., p. 169.

28 LAJOVIC, Anton. Ljubljanska 'Philharmonische Gesellschaft' in Slovenci II. Slovenski narod, 52, no. 250, 23 December 1919, p. 1-2.

29 SCHWEIGER. Philhamonische Gesellschaft in gospod Lajovic. Naprej: Glasilo jugoslovanske socialno demokratične stranke, 4, no. 4, 6 Januar 1920, p. 3. 


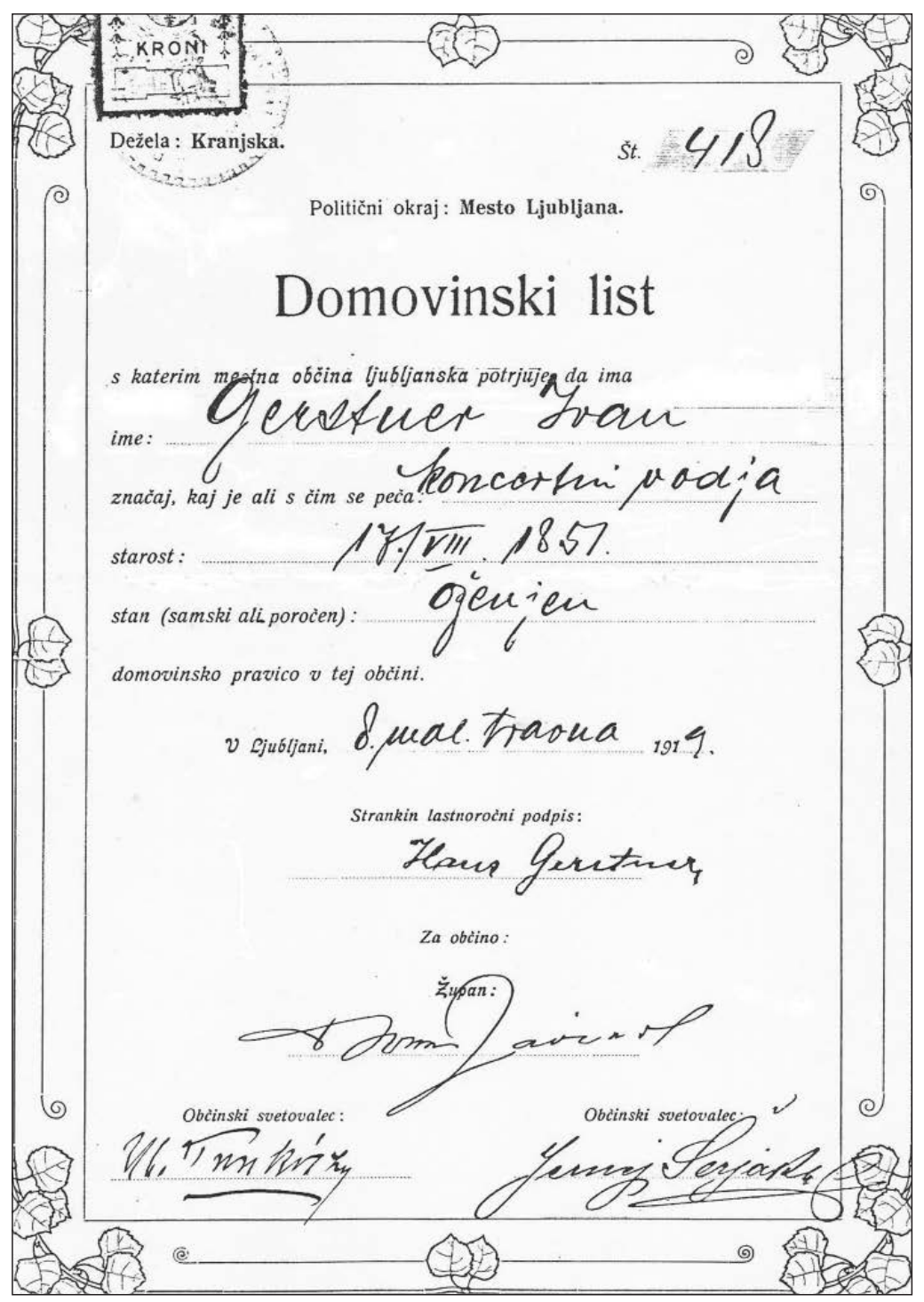

Fig. 3 On 8 April 1919, Gerstner was granted citizenship of the new state of the south Slavs. In his citizenship card, Hans was rechristened to Ivan Gerstner; the document was signed by the then Ljubljana Mayor Ivan Tavčar.

With power on his side, Lajovic flatly and ruthlessly dismissed all criticism, claiming that the "Germans want to keep the Society in their German grasp by any means and for all times". ${ }^{30}$

30 LAJOVIC, Anton. Ljubljanska 'Philharmonische Gesellschaft' in Slovenci II, op. cit., p. 3. 
While the Philharmonic Society officially didn't cease to exist, it had a very limited scope of activity. On 19 July 1921, it was annexed to the Glasbena Matica as its subsidiary, the Philharmonic Club, and was formally dissolved only in $1945 .{ }^{31}$ The main philharmonic hall, the Tonhalle, suffered an equally ignoble fate as its erstwhile administrator. In the post-war years, it first served as storage space, then housed the Kino Matica cinema from 1923 onwards.

Lajovic's post-war actions seem in great measure shaped by German nationalist policy, which especially from the end of the seventies took a marked hold on the monarchy. The reasons for the post-war revanchism and settling of scores with German individuals and institutions could also be sought in some earlier attacks on Slovene musicians and societies. Nevertheless, the fact is that in the changed circumstances after the First World War Lajovic was incapable of exploiting the international renown of the Philharmonic Society, its connections or its lengthy tradition of organising symphonic concerts. The distinguished past of the Philharmonic Society pretty much overnight ended on the scrap heap of history. Although the Glasbena Matica had a complete monopoly after the First World War, concert life without the permanent orchestra and with an increasingly obvious lack of Slovene symphonic literature was at an all-time low. Foreign artists made only rare appearances, and foreign orchestras were almost never featured.

Thus, in the period immediately after the First World War, the Glasbena Matica music society was financially and personally unable to realise the role of the leading institution in the Slovene music culture. It was precisely because of the expansion of its activity (first and foremost the founding of the Conservatory) the Glasbena Matica ended up in considerable financial difficulty. In 1921 at all three levels (primary, secondary and tertiary) the Conservatory had around a thousand students and almost 50 employees, costing more than a million crowns, while through tuition fees they were only able to earn around 700,000. So they had more than 300,000 crowns of debt each year. ${ }^{32}$ Gradually, the state took over a larger share of the Conservatory's financing. Following its nationalisation, it was renamed the State Conservatory in 1926 and was financed entirely by the state beginning with the 1926/27 academic year.

Directly after the war the nationalised music institutions such as the National Theatre Opera in Ljubljana were therefore in a significantly better position. Thus during the leadership of Mirko Polič, which marked a major part of the period between the wars at the Ljubljana Opera, operatic novelties [such as Oedipus Rex by Igor Stravinsky, Shostakovich's Lady Macbeth, Křenek's Jonny spielt auf or Novák's Laterna and equally one of the most prominent achievements of Slovene musical expressionism, the opera Črne maske ["Black Masks"] by Marij Kogoj] entered the repertoire of the Ljubljana Opera with previously unimaginable rapidity (and Wagner also remained on the list of most frequently performed composers at the Ljubljana Opera). ${ }^{33}$ Undoubtedly, we have Polič's

31 KURET, Primož. Ljubljanska filharmonična družba, op. cit., p. 443.

32 BUDKOVIČ, Cvetko. Razvoj glasbenega šolstva na Slovenskem II: od nastanka konservatorija do Akademije za glasbo 1919-1946. Ljubljana: Znanstveni inštitut Filozofske fakultete, 1995, p. 24-25.

33 WEISS, Jernej. Wagner on Ljubljana’s Concert and Opera Stages. Muzikološki zbornik 49, 2013, no. 2, p. $65-67$. 
artistic breadth, in contrast to the quite limited programme orientation of some of his contemporaries, to thank for the fact that despite the new politico-cultural reality the Opera evinced absolutely no pronounced tendencies towards any Slavo-centric political propaganda strategy, such as was advocated in the post-war years by, for instance, Hubad or Lajovic. Although here, of course, there is a fundamental reservation among repertory and other comparisons of societies such as the Glasbena Matica on the one hand and the already nationalised music institutions such as the Opera on the other hand, this type of anti-German ideology, which was primarily intended to animate membership, was more or less expected in such societies.

Although the new cultural policy after the war ended the significant musical past of the German Provincial Theatre and Philharmonic Society (the consequence of which was primarily the great absence of symphonic music in Ljubljana) the post-war nationalisation on the other hand brought gradual professionalisation and specialisation of musical life for the majority of Slovenia's newly established music institutions. In just a short time following the First World War, with its university, national theatre and conservatory, Ljubljana acquired a range of long-anticipated professional cultural and academic institutions of central national importance. Of course, the importance of these institutions lay not just in the cultural or academic mission of their work. Equally important or, for some contemporaries, even more important is the fact that the process of creating these institutions signified a decisive step towards the national emancipation of Slovenes into the circle of culturally developed nations.

\section{Bibliography}

\section{Sources}

\section{Archive sources}

Die Philharmonische Gesellschaft in Laibach, 20 October 1910, Ljubljana, Gesellschaft der Musikfreunde in Wien, Archiv.

GERSTNER, Hans. Ein Leben für die Musik. Hans Gerstner, 17.08.1851, Luditz - 09.01.1939, Laibach. Unpublished manuscript, Archive, Sudetendeutsches Musikinstitut, Regensburg.

\section{Periodical sources}

HUBAD, Matej. Jugoslovanski konservatorij Glasbene Matice v Ljubljani. Učiteljski tovariš, vol. 59, no. 35, 27 August 1919, p. 1.

KREK, Gojmir. Dostavek uredništva. Novi akordi: glasbeno-književna priloga 13, 1914, no. 1, p. 23. 
LAJOVIC, Anton. Ljubljanska 'Philharmonische Gesellschaft' in Slovenci II. Slovenski narod, 52, no. 250, 23 December 1919, p. 1-2.

LAJOVIC, Anton. O večnih krasotah in o strupu Beethovnovih, Bachovih in Wagnerjevih del. Slovenec, no. 80, 6 April 1924, p. 5.

N. Narodno gledališče. Slovenski narod, no. 288, 4 December 1918, p. 3.

SCHWEIGER. Philhamonische Gesellschaft in gospod Lajovic. Naprej: Glasilo jugoslovanske socialno demokratične stranke, 4, no. 4, 6 Januar 1920, p. 3.

\section{Literature}

Ustanovitev gledališke komisije. Uradni list deželne vlade za Slovenijo, I, no. 165, 26 November 1919, p. 606.

BUDKOVIČ, Cvetko. Razvoj glasbenega šolstva na Slovenskem II: od nastanka konservatorija do Akademije za glasbo 1919-1946. Ljubljana: Znanstveni inštitut Filozofske fakultete, 1995.

KRSTULOVIĆ, Nataša Cigoj. Zgodovina, spomin, dediščina: Ljubljanska Glasbena matica do konca druge svetovne vojne. Ljubljana: Založba ZRC, 2015.

DUFNER, Jens. Beethoven Werke, Symphonien III. München: Franz Steiner Verlag, 2013.

GERSTNER, Hans Jr. Die Philharmonische Gesellschaft in Laibach. In Südostdeutsche Vierteljahresblätter, Sonderdruck aus Heft Nr. 3, 1972, p. 168-169.

KOTER, Darja. Slovenska glasba 1848-1918. Ljubljana: Študentska založba, 2012, p. 267.

KURET, Primož. Filharmonična družba - najstarejše glasbeno društvo v monarhiji. Slovenska kronika XIX. stoletja. Ljubljana: Nova revija, 2001, p. 48.

KURET, Primož. Ljubljanska filharmonična družba 1794-1919: kronika ljubljanskega glasbenega življenja v stoletju meščanov in revolucij. Ljubljana: Nova revija, 2005.

LAH, Špela. Slovensko-nemška dihotomija v Deželnem gledališču v Ljubljani med letoma 1892 in 1914. Muzikološki zbornik 46, 2010, no. 2, p. 95-108.

MATIĆ, Dragan. Nemci v Ljubljani: 1861-1918. Ljubljana: Oddelek za zgodovino Filozofske fakultete, 2002.

MORAVEC, Dušan (ed.). Repertoar slovenskih gledalǐ̌č 1867-1967. Ljubljana: Slovenski gledališki muzej, 1967, p. 181-201.

WEISS, Jernej. 'Even Amidst the Clash of Conflict, the Sweet Sounds of the Muses did not Fade Away Completely': The Concert Life of the Philharmonic Society in Ljubljana in the Period of its Last Music Director Hans Gerstner. Muzikološki zbornik 53, 2017, no. 2, p. 149-171.

WEISS, Jernej. Med provincialno opereto in nacionalno opero Foersterjev Gorenjski slavček. In Musica et artes. Koper: Založba Univerze na Primorskem; Ljubljana: Akademija za glasbo: Festival Ljubljana: Slovenska filharmonija, 2015, p. 59-75.

WEISS, Jernej. Wagner on Ljubljana’s Concert and Opera Stages. Muzikološki zbornik 49, 2013, no. 2, p. 27-74.

WEISS, Jernej. Hans Gerstner (1851-1939): življenje za glasbo. Maribor: Litera, 2010.

ZANGGER, Fritz. Das ewige feuer im fernen Land: Ein deutsches Heimatbuch aus dem Südosten. Celje: Druckerei u. Verlags AG, 1937, p. 98. 
